\title{
Analysing and Interpreting the Concept and Possible Implementation of Herd Immunity in the Human Population against COVID 19 Infections
}

\author{
Halim $\mathrm{M}^{1^{*}}$, Halim $\mathrm{A}^{2}$, Trivana $\mathrm{V}^{3}$ \\ ${ }^{1}$ University of Salford, MSc Biomedical Science, Greater Manchester, United Kingdom \\ ${ }^{2}$ Zhong Shan Hospital, Shanghai Medical College, Fudan University, Shanghai, China \\ ${ }^{3}$ College of Civil Engineering, Tongji University, Shanghai, China
}

Corresponding Author: Michael Halim

Address: University of Salford, MSc Biomedical Science, Greater Manchester, United Kingdom; Email: michaelhalim10oo@gmail.com

Received date: 24 September 2020; Accepted date: 23 October 2020; Published date: 30 October 2020

Citation: Halim M, Halim A, Trivana V. Analysing and Interpreting the Concept and Possible Implementation of Herd Immunity in the Human Population against COVID 19 Infections. J Health Care and Research. 2020 Oct 30;1(3):172-81.

Copyright (c) 2020 Halim M, Halim A, Trivana V. This is an open-access article distributed under the Creative Commons Attribution License, which permits unrestricted use, distribution, and reproduction in any medium, provided the original work is properly cited.

\begin{abstract}
Introduction: Herd immunity refers to developing immunity in individuals by acquiring natural immunity or through vaccination. The Severe Acute Respiratory Syndrome-Corona Virus-2 (SARS-CoV-2) was first reported in a city in China, Wuhan. Currently, no vaccines are available to treat and cure the Covid-19 pandemic.
\end{abstract}

Methods: Information was gathered from electronic databases such as PubMed and Google Scholar. These articles were checked for relevance with recent articles and journals were included while older ones were excluded. Data analysis was then performed using MS Excel and SPSS.

Results: Current epidemiological evidence suggests different countries have varying infection rates, therefore varying rates of reproduction number. The current minimum threshold required for herd immunity currently stands between 50-66.67\%, although rates vary differently across the globe.

Conclusion: A vaccine development is anticipated to be critical in controlling the Covid-19. However, there are several limitations, including changing and managing trends at the virus epitope, differences in the reproduction number across different countries and varying geographical locations, underreporting of infection rates across countries across the globe, and the varying infectious nature of the virus among the demographic population. Regarding the presented information, the vaccine development would significantly accelerate herd immunity and play a key role in managing the disease.

\section{Keywords}

Herd Immunity, Vaccine, SARS-CoV-2, Covid-19, Epidemiology, Pandemic, Natural Immunity, Virus

\section{Herd Immunity Concepts}

The herd immunity model was founded on the premise that vaccines can be administered to protect populations against specific diseases. e.g. polio and smallpox [1]. These diseases are viral, and human beings are considered as reservoirs. Therefore, herd immunity refers to population protection from diseases by having certain individuals within a 
Citation: Halim M, Halim A, Trivana V. Analysing and Interpreting the Concept and Possible Implementation of Herd Immunity in the Human Population against COVID 19 Infections. J Health Care and Research. 2020 Oct 30;1(3):172-81.

community with the immunity against disease [2]. Herd immunity demonstrates an equilibrium between the microorganism and the people at risk [3]. Conceptually, it is a subset of the population with acquired active immunity either through prophylactic immunization or previous infection [4]. These patients offer protection to the entire community by significantly reducing the existing disease burden and the rate of its spread to the remaining population [5].

Herd immunity remains the best practical approach used in the fight against infectious disease, and it has also been applied to other diseases, including rubella [6], measles [7], and influenza [8]. The effectiveness of herd immunity is dependent on four factors, including vaccine safety and effectiveness, diseasecarrying substantial health risk, and high risk of contracting the disease [7]. Within a population that is considered to be naïve, the pathogen is more likely to propagate through the host in an unchecked manner making more people infected. However, if the same population has some form of immunity, there are lower possibilities of significant contact between susceptible and infected individuals since most hosts have an immune system that cannot transmit the pathogen [9]. If only a small section of an entire population is susceptible while the remaining are immunized, the pathogen will not spread successfully, and consequently, a decline in prevalence rates will be observed [10]. Such a point where the predisposed number of victims' drops below the transmission threshold is referred to as herd immunity (Fig-1).

Covid-19 adheres to these principles, being that no vaccine is considered as being safe and effective. The herd immunity application in Covid-19 is also significantly limited by its highly infectious nature and the high mortality rate, as presented in the graphs below (Fig-2).

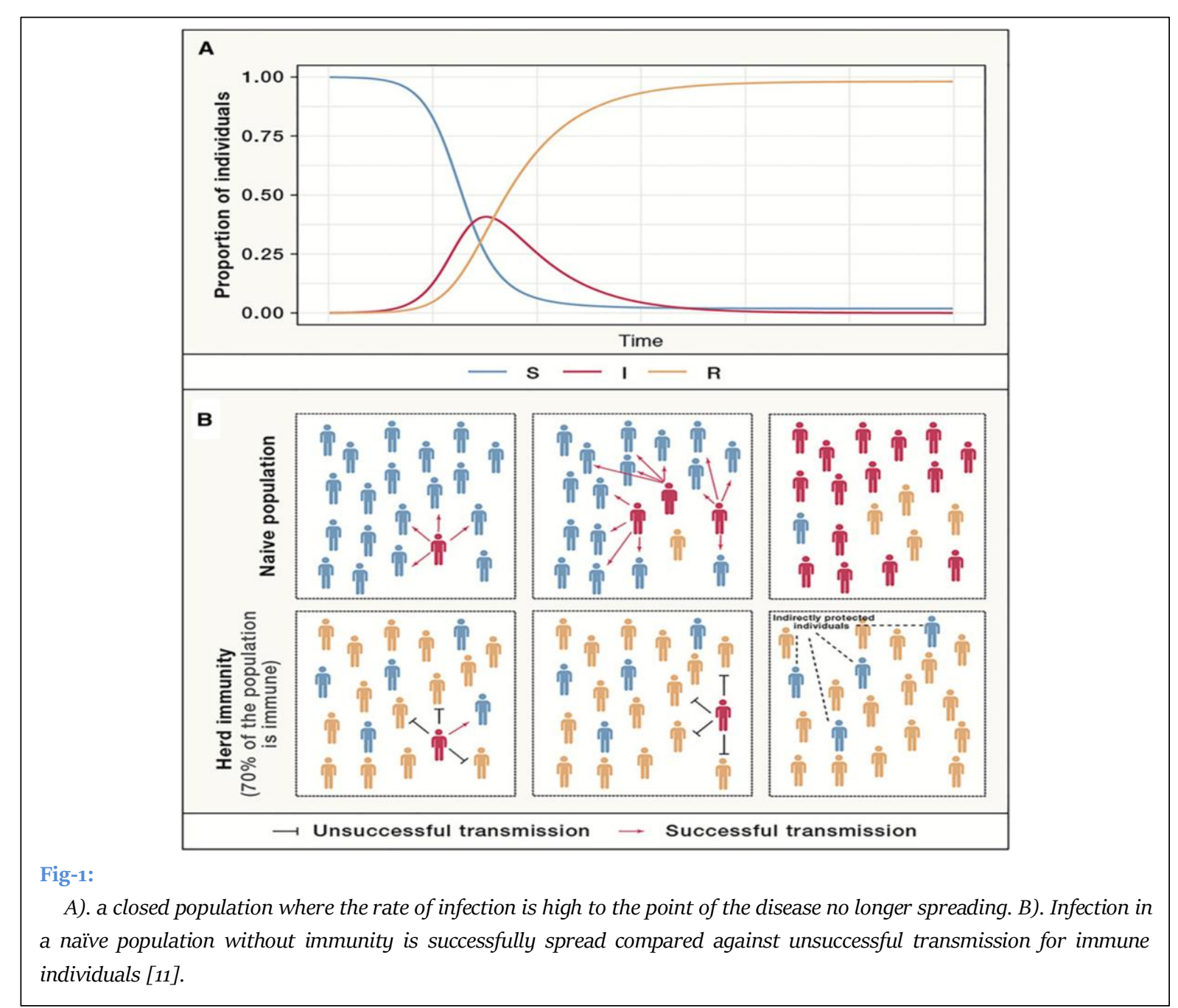


Citation: Halim M, Halim A, Trivana V. Analysing and Interpreting the Concept and Possible Implementation of Herd Immunity in the Human Population against COVID 19 Infections. J Health Care and Research. 2020 Oct 30;1(3):172-81.

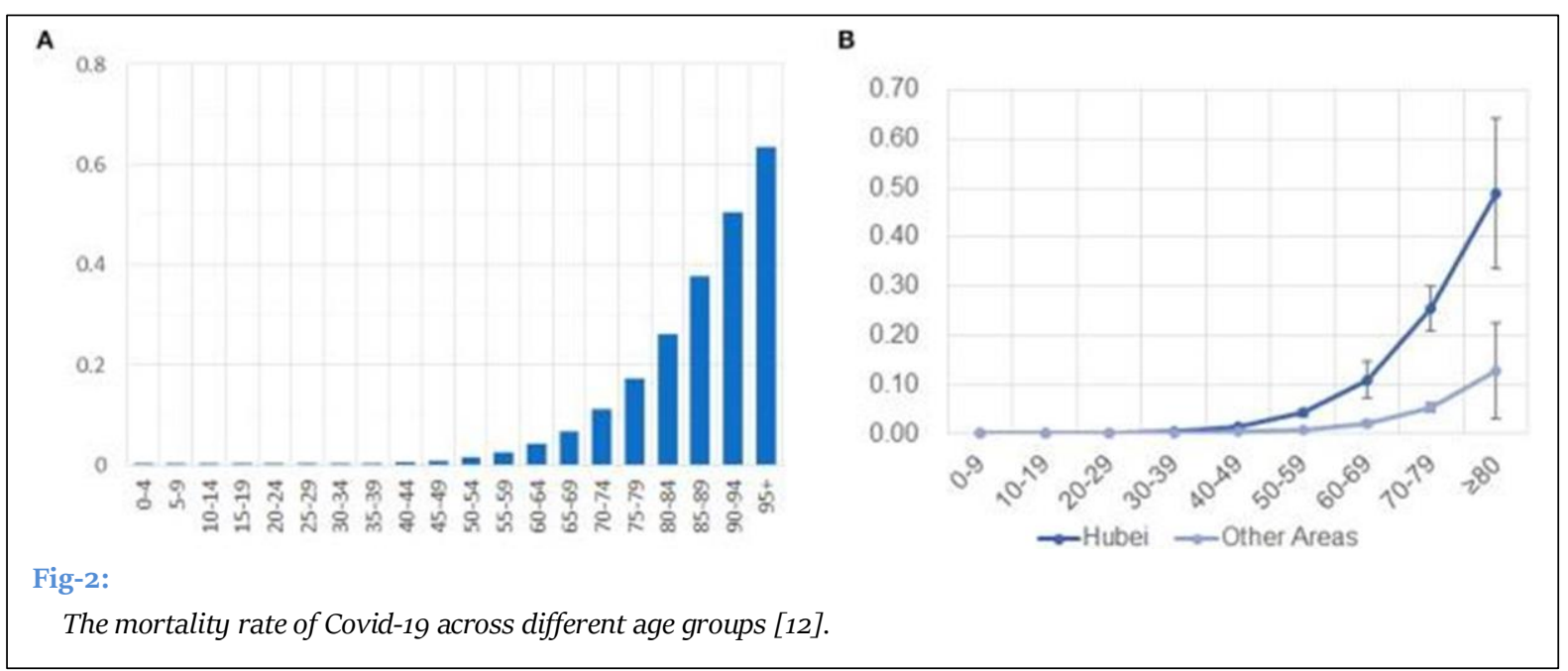

\section{Methods}

\section{Database Searches:}

An electronic search was conducted across reputable medical databanks, E.g. PubMed, and Google Scholar. Elsevier, amongst other publishers, was also examined. Keywords and Boolean operators used during the search are "herd immunity," "SARS-CoV-2", "Covid19", "epidemiology,” AND “natural immunity."

\section{Article Screening:}

The selected medical journals and articles were checked to ensure they were relevant and contained the required keywords before they were included.

\section{Inclusion and Exclusion Criteria:}

The criteria of inclusive only focused on articles and journals published between 2019 and 2020, similar to cases of studies and experiments conducted on COVID19. Included in the study were the modeling cases of herd immunity. Earlier studies and insufficient evidence regarding the COVID-19 infections were excluded from the analysis.

\section{Graphing Software:}

MS Excel was suitable for creating tables, graphs, and data analysis. However, SPSS was used in cases that required detailed statistical analysis to examine the relationship between various variables.

\section{Results}

Basic Reproductive Number and Herd Immunity:

The basic reproductive number is considered the secondary cases a predisposed population generates from an infectious individual [13]. Rt represents the real-life productive number of any population. It is utilized as an estimate of reproductive numbers during changes in an epidemic [14]. An outbreak is considered to continue if the Ro value is higher than one and ends when the Ro value is below 1 [1]. The potential size of any outbreak is therefore determined by the Ro value size $[1,13]$. Ro also determines the specific population segment that requires vaccination to eliminate rates of infection. For instance, Ebola in Guinea had a Ro value of 1.51 [15], while the Zika virus in South America had a Ro value of 2.06 [16].

Hypothetically, if the multiplicative number is 4 , it means that on average, an individual infects four other people during the infectious period provided that immunity of the population has not developed just yet. For the herd immunity to be attained,

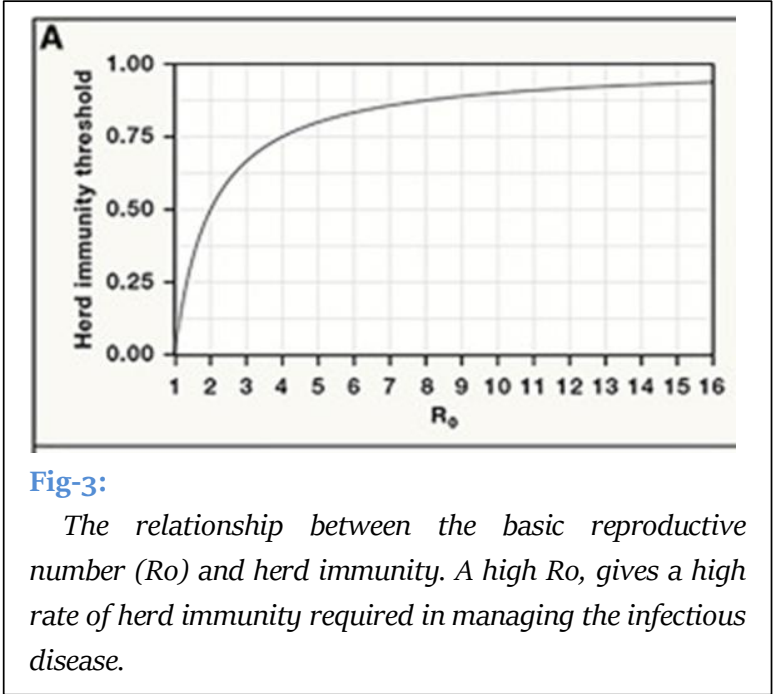


Citation: Halim M, Halim A, Trivana V. Analysing and Interpreting the Concept and Possible Implementation of Herd Immunity in the Human Population against COVID 19 Infections. J Health Care and Research. 2020 Oct 30;1(3):172-81.

the formulae $\left[1-\frac{1}{\text { reproductive number }}\right]$, is normally calculated. In the above context, the threshold for herd immunity is 0.75 or $75 \%$ of a given population. Thus, the more contagious a contagion is, the greater the basic reproductive number and a higher probability that the population will be immune to prevent transmission. As in Fig-3 below, a rise in the reproductive rate characterizes the rate of herd immunity, whereas Fig-4 provides information about the threshold immunity for different viral diseases.

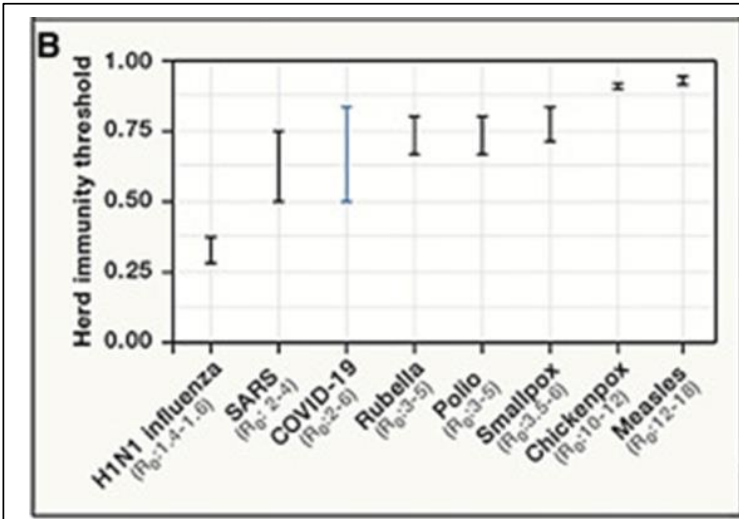

Fig-4:

Herd immunity rate for different infectious diseases.
The herd immunity required for Covid-19 is approximately 0.50 to 0.80 . Certain Diseases, E.g. measles, and chickenpox have a higher threshold of herd immunity as compared to Covid-19.

The Rt value for COVID-19 across different countries was recently calculated depended on the infectious nature of the disease as late as March 2020. The Ro was initially estimated to range between 1.4 to 2.5 at the onset of the outbreak [17]. However, subsequent research reported higher values varying from 1.5 to 6.68 , suggesting the mean value as 3.28 when the median value was 2.7 [18]. The base value for population immunity obtained either naturally or through population immunity to halt the immunity was provided. On the results presented below, the multiplicative number was significantly high across various countries (Table-1). However, the minimum population required to recover from granting immunity, or the resulting herd immunity is significantly high, showing that herd immunity was far from being achieved in many countries [19].

Table-1: The reproductive number of different countries and the minimum threshold for immunity

\begin{tabular}{|c|c|c|c|c|}
\hline Study & Countries & $\begin{array}{c}\text { Population infected by } \\
\text { Covid-19 }\end{array}$ & $\begin{array}{l}\text { Reproductive } \\
\text { number }\end{array}$ & $\begin{array}{l}\text { Minimum number of } \\
\text { people required to recover } \\
\text { to confer immunity }\end{array}$ \\
\hline \multirow{2}{*}{ Rt greater than 4} & Denmark & 804 & 5.08 & $80.30 \%$ \\
\hline & Finland & 155 & $4 \cdot 52$ & $77.90 \%$ \\
\hline \multirow{2}{*}{ Rt between than $2-4$} & Austria & 504 & 3.97 & $74.80 \%$ \\
\hline & Portugal & 996 & 3.74 & $73.30 \%$ \\
\hline \multirow{2}{*}{ Rt between than 1-2 } & Australia & 199 & 1.86 & $46.20 \%$ \\
\hline & Belgium & 559 & 1.75 & $42.90 \%$ \\
\hline
\end{tabular}

The SARS-CoV-2 Herd Immunity and Case Fatality:

Growth and development of herd immunity are dependent on the presence or absence of the vaccine [20]. In the absence of a vaccine, the overall mortality rate representing those who pass away due to complications, and the fatality rate of infection representing infected individuals must be considered [21]. A combination of infection fatality rate and herd immunity is commonly used to provide adequate information regarding the mortality rate that may be expected, especially where there is no vaccine $[22,23]$. 
Citation: Halim M, Halim A, Trivana V. Analysing and Interpreting the Concept and Possible Implementation of Herd Immunity in the Human Population against COVID 19 Infections. J Health Care and Research. 2020 Oct 30;1(3):172-81.

\section{Literature Review}

An elastic herd immunity of approximately $67 \%$ based on a basic multiplicative number of a contagion fatality rate of $0.6 \%$ would result in the death of approximately 30 million people, as indicated in Fig-5 below.

\section{Issues associated with SARS-Cov-2 Herd} Immunity:

Several issues emerge regarding herd immunity with SARS-CoV-2. First, SARS-Cov-2 remains a novel pathogen with numerous features not being fully characterized [24,25]. Numerous features closely related to viral infection, as well as its spread, are still under consideration, and therefore, the current basic reproductive number does not factor in the above complexities [26,27]. Also, numerous differences exist among population age structures, cultural behaviors, population densities, and contact rates, which directly affect the elementary reproduction number [28,29]. The present elementary number of reproduction does not account for super spreading events that consist of a sole individual having a significantly large number of ancillary contacts and has been shown to drive outbreaks of past diseases, including MERS [30].

Calculations regarding the minimum threshold required for herd immunity for SARS-CoV-2 are currently between $50 \%$ to $67 \% \%$ [19]. However, the threshold may be underreported, considering the numerous asymptomatic incidences associated with SARS-CoV-2. Also, a significant portion of people has recovered since the last time studies were reported on the minimum threshold of herd immunity [31,32]. Thus, if numbers are underestimated, then a possibility that a substantially high population might require to be immunized against SARS-CoV-2 before herd immunity is conferred [33]. Also, herd immunity is not easy to attain uniformly across the entire globe, considering the differences in levels of contagion and recovery rates of individuals across the globe [34,35]. Individual differences in the elementary multiplicative number have been reported in several regions within the same country, with Italy being a case study where the country's northern area reported higher Ro than the southern part [36]. The variation seen in the figure of recovered populations across various regions implies that the immediate control of the spread of the virus would not be easy [37]. Countries that reported a significantly lower level of infections may take a longer time to attain herd immunity [38].

Current results on the protective immunity against SARS-CoV-2 are undefined. Data concerning follow-up studies from the SARS-CoV-2 infected persons can already provide detailed responses to the immune. Cohort studies indicate that specific antibodies against

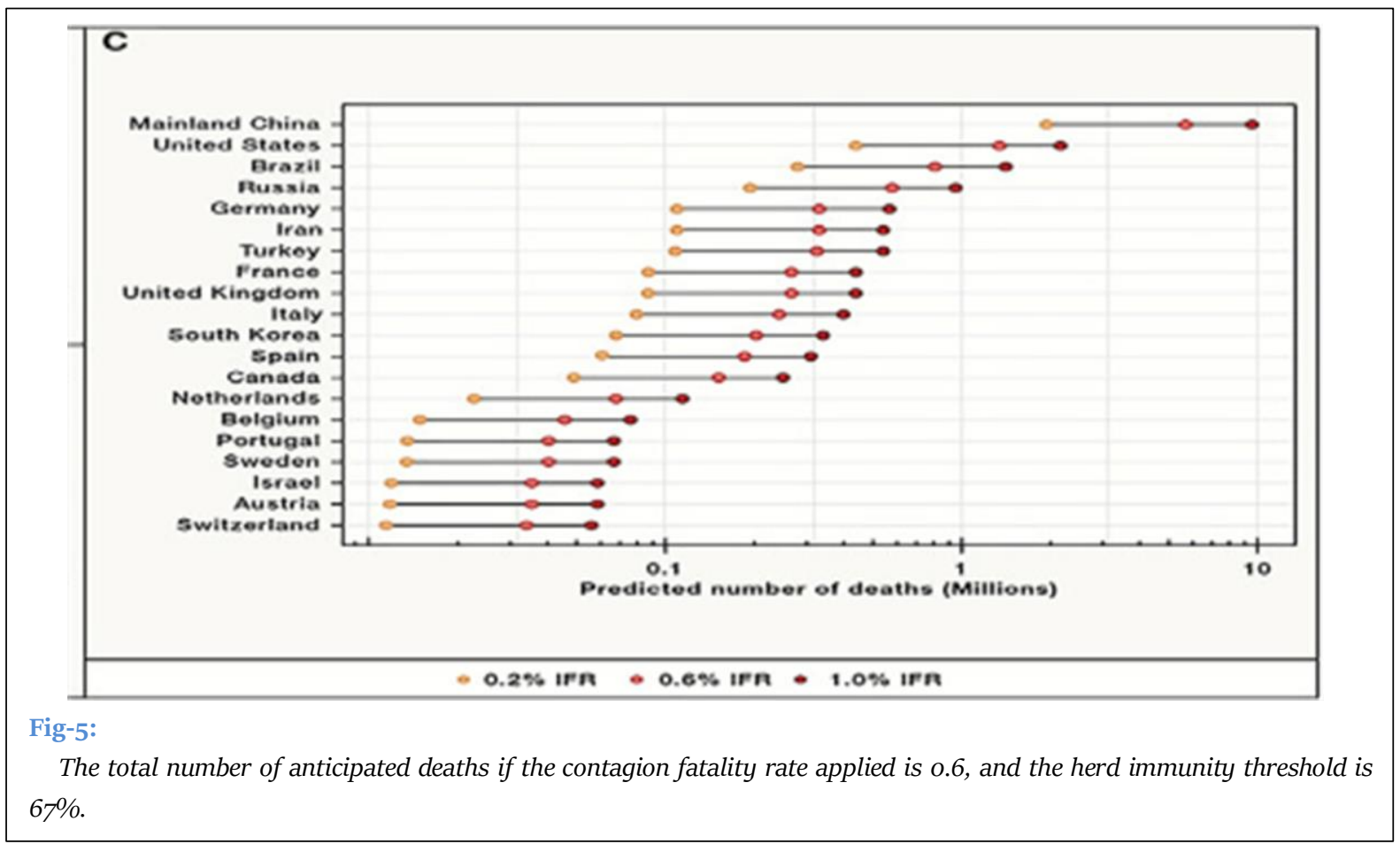


Citation: Halim M, Halim A, Trivana V. Analysing and Interpreting the Concept and Possible Implementation of Herd Immunity in the Human Population against COVID 19 Infections. J Health Care and Research. 2020 Oct 30;1(3):172-81.

\section{Literature Review}

SARS-CoV and not SARS-CoV-2 produced T-cell responses, which lasted past a decade, although the protective effect remained unknown [39]. The span of protective immunity for SARS-CoV-2 dictates the virus' pandemic and post-pandemic transmission since recent information has not indicated a lasting protective effect against SARS-CoV-2 [40,41]. Antibody responses against SARS-CoV-2 have not demonstrated

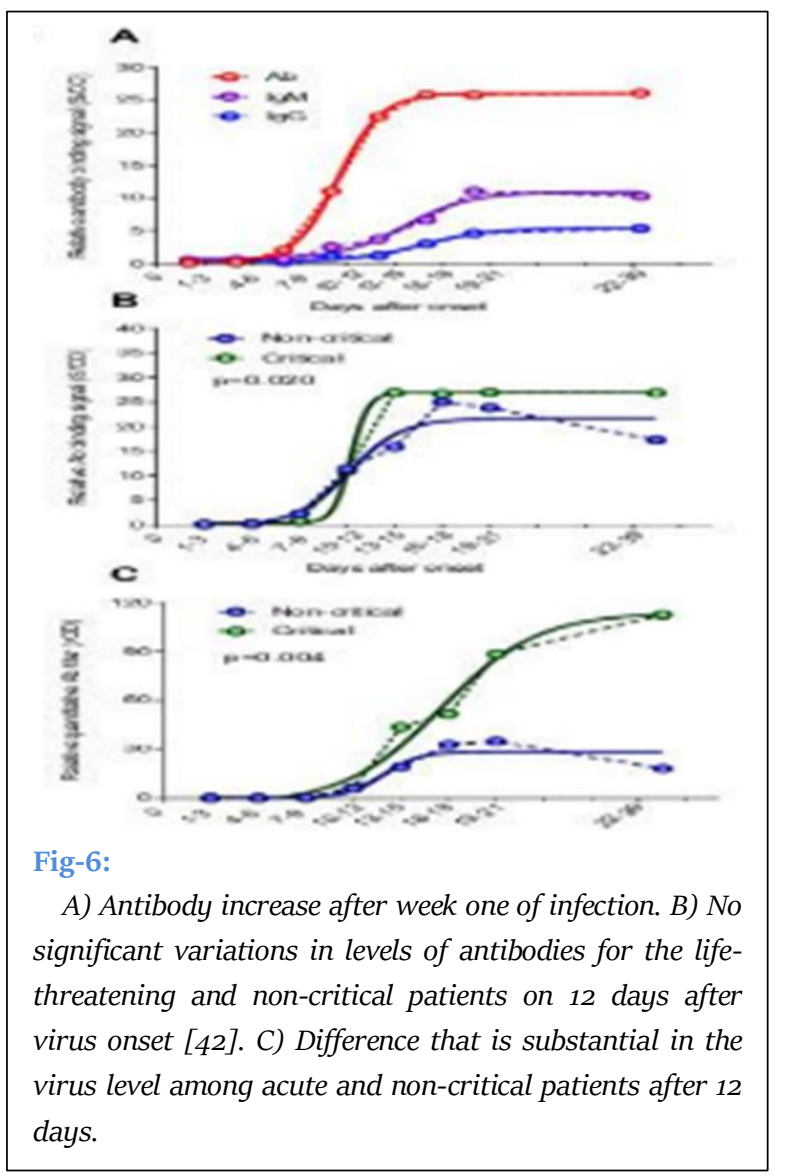

a sharp decrease in the viral load [42]. A rise in the level of antibody titers is not accompanied by a decline or clearance with the levels of viral RNA, particularly for the more critical patients suggesting that the antibody response being produced is not sufficient to clear the virus as presented in Fig-6 [43]. Also, antibody production differs based on several conditions, including the specific age of a population, with younger people reporting higher antibody production than older individuals, as presented in Fig-7 [44]. Similarly, high levels of CRP proteins are also observed in SARS-CoV-2 patients $[45,46]$.

Lastly, the stability of the current viral epitopes may significantly change, resulting in mutants being developed [47]. The infectious or lethal nature of COVID-19 might significantly increase due to mutation events [48]. The latest COVID-19 mortality rate is approximately the same as seasonal flu but not higher than the previous infections of SARS-CoV-2 and MERS$\mathrm{CoV}[49,50]$. A virus of a higher significant infection rate affects the host more rapidly, resulting in death. Viral infections associated with fewer fatality levels permit the infected individual to initiate a resistant response resulting in selection pressure that allows the evolution of mutants over time. Consequently, the rising number of individuals recovering from COVID19 might not attain herd immunity, especially when the viruses mutate.

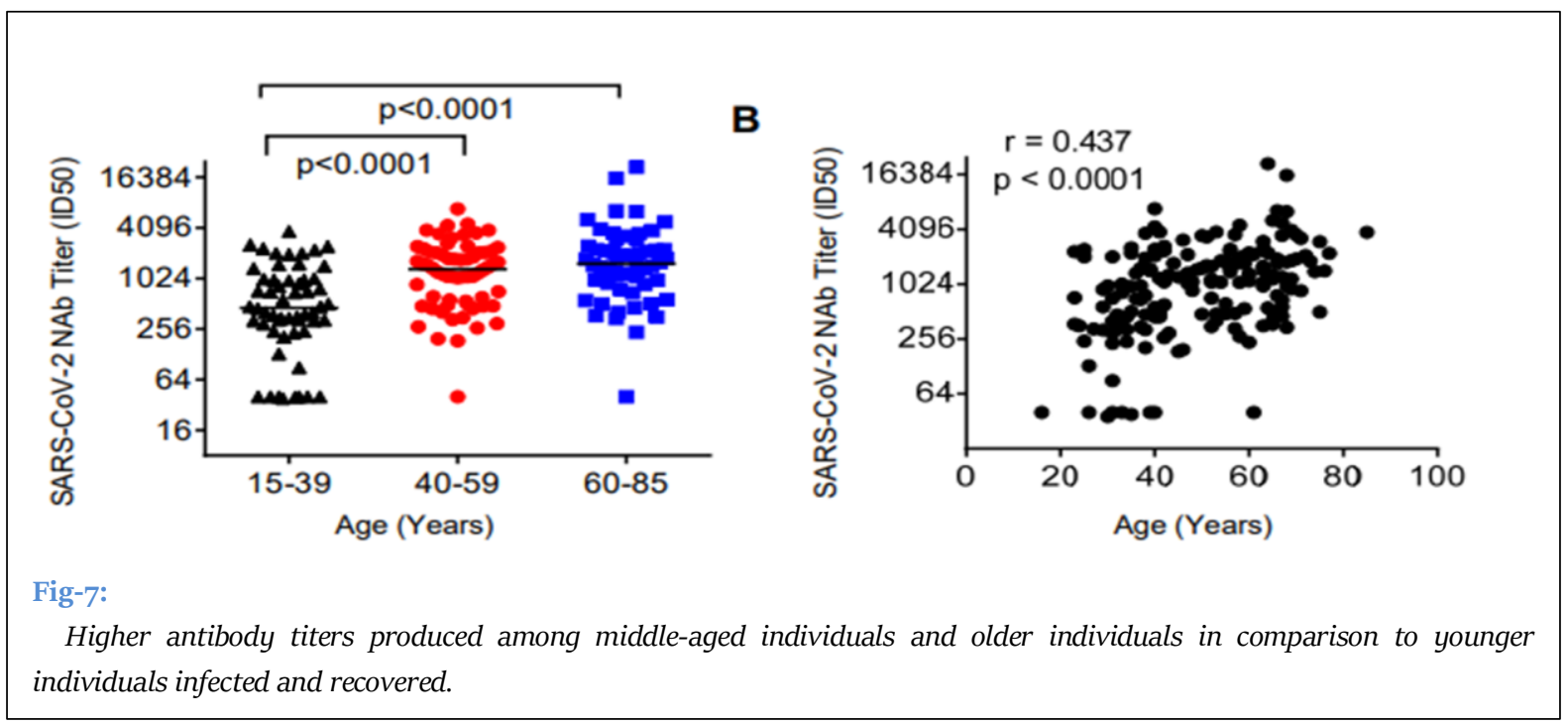




\section{Summary}

Herd immunity is responsible for protecting vulnerable individuals within a population by reducing contacts between infected and healthy individuals. Once the threshold of herd immunity is attained, herd immunity takes action. No transmissions can occur and hence a subsequent reduction in the number of infected individuals. The scale of protection depends on the epidemiology and immune features of a population and should be taken into account to eliminate widespread SARS-COV-2. Mass vaccinations and natural immunization are important for enabling individuals to build herd immunity.

\section{Meta-Analysis}

Significantly, the development of vaccines should be properly analyzed. It involves four essential steps, development of well-defined criteria before data collection from several studies. Studies are assessed for the prospect of being combined before generating appropriate conclusions. The vaccine developed in this meta-analysis should take into account immunogenic, efficacy, and safety factors.

\section{Conclusion and Recommendation}

Herd immunity reduces the rate at which the disease is spread and is commonly achieved either naturally or through vaccination when individuals recover from the infection. The herd immunity effectiveness is dependent on several factors, including the percentage of individuals who are immune, stability of the viral epitopes in line with the duration and efficiency of an immune response. The Growth and development of herd immunity in managing COVID-19 might be more difficult considering the numerous factors indicated above. Research on the protective effects of antibodies against the virus has not indicated positive results. Significant differences are also observed among various populations across the entire globe, more specifically, critically ill and non-critical. Also, currently, the estimated herd immunity threshold is put at $50 \%$ to $67 \%$ when applied without a vaccine, which may significantly result in the deaths of a million people. Immunity against SARS-CoV-2 among all infected individuals is not directly associated with total viral clearance, and protective immunity is not entirely associated with having the virus. Also, the virus nature allows for the development of the mutant strains, which in time may increase its lethality or infectious nature. Considering the above factors, containing the current outbreak and prevent the potential of further outbreaks, an operative vaccine is urgently required.

\section{Future Perspective}

Further research is required to be done on the fundamental value of herd immunity against SARSCov-2. More research should also be focused on the effect of the varying infection rates across different countries on attaining the required minimum threshold. Also, future studies should be on identifying factors that affect minimum threshold levels, such as changes in virus mutations.

\section{Conflict of Interest}

All authors have read and approved the final version of the manuscript. The authors have no conflicts of interest to declare.

\section{References}

[1] Guerra FM, Bolotin S, Lim G, Heffernan J, Deeks SL, Li Y, Crowcroft NS. The basic reproduction number $\left(\mathrm{R}_{\mathrm{o}}\right)$ of measles: a systematic review. Lancet Infect Dis. 2017 Dec;17(12):e420-28. [PMID: 28757186]

[2] Betsch C, Böhm R, Korn L, Holtmann C. On the benefits of explaining herd immunity in vaccine advocacy. Nat Hum Behav. 2017 Mar 6;1(3):1-6..

[3] Kalla IS, Laher A. COVID-19: The concept of herd immunity - is it a strategy for South Africa? Wits J Clin Med. 020 Apr; 2(SI):39-42.

[4] Sobo EJ. What is herd immunity, and how does it relate to pediatric vaccination uptake? US parent perspectives. Soc Sci Med. 2016 Sep;165:187-95. [PMID: 27497915]

[5] Metcalf CJE, Ferrari M, Graham AL, Grenfell BT. Understanding Herd Immunity. Trends Immunol. 2015 Dec;36(12):753-55. [PMID: 26683689]

[6] Kinoshita R, Nishiura H. Assessing herd immunity against rubella in Japan: a retrospective seroepidemiological analysis of age-dependent transmission dynamics. BMJ open. 2016 Jan 1;6(1).

[7] Mallory ML, Lindesmith LC, Baric RS. Vaccinationinduced herd immunity: Successes and challenges. J Allergy Clin Immunol. 2018 Jul;142(1):64-66. [PMID: 


\section{9]}

[8] Kim TH. Seasonal influenza and vaccine herd effect. Clin Exp Vaccine Res. 2014 Jul;3(2):128-32. [PMID: 25003085]

[9] Pollard SL, Malpica-Llanos T, Friberg IK, FischerWalker C, Ashraf S, Walker N. Estimating the herd immunity effect of rotavirus vaccine. Vaccine. $2015 \mathrm{Jul}$ 31;33(32):3795-80o. [PMID: 26116250]

[10] Chen J, Ye L, Zhou MY, Cheng YR, Wang MW, Feng ZH. Herd immunity and COVID-19. Eur Rev Med Pharmacol Sci. 2020 Apr;24(8):4064-65. [PMID: 32374011]

[11] Randolph HE, Barreiro LB. Herd Immunity: Understanding COVID-19. Immunity. 2020 May 19;52(5):737-41. [PMID: 32433946]

[12] Li H, Wang S, Zhong F, Bao W, Li Y, Liu L, Wang $\mathrm{H}$, He Y. Age-Dependent Risks of Incidence and Mortality of COVID-19 in Hubei Province and Other Parts of China. Front Med (Lausanne). 2020 Apr 30;7:190. [PMID: 32426363]

[13] Delamater PL, Street EJ, Leslie TF, Yang YT, Jacobsen KH. Complexity of the Basic Reproduction Number $\left(\mathrm{R}_{0}\right)$. Emerg Infect Dis. 2019 Jan;25(1):1-4. [PMID: 30560777]

[14] Xu C, Dong Y, Yu X, Wang H, Tsamlag L, Zhang S, Chang R, Wang Z, Yu Y, Long R, Wang Y, Xu G, Shen T, Wang S, Zhang X, Wang H, Cai Y. Estimation of reproduction numbers of COVID-19 in typical countries and epidemic trends under different prevention and control scenarios. Front Med. 2020 May 28:1-10. [PMID: 32468343]

[15] Althaus CL. Estimating the Reproduction Number of Ebola Virus (EBOV) During the 2014 Outbreak in West Africa. PLoS Curr. 2014 Sep 2;6. [PMID: 25642364]

[16] Chan JF, Choi GK, Yip CC, Cheng VC, Yuen KY. Zika fever and congenital Zika syndrome: An unexpected emerging arboviral disease. J Infect. 2016 May;72(5):507-24. [PMID: 26940504]

[17] WHO (World Health Organization). Statement on the meeting of the International Health Regulations (2005) Emergency Committee regarding the outbreak of novel coronavirus (2019-nCoV). WHO News; 2020.

[18] Liu Y, Gayle AA, Wilder-Smith A, Rocklöv J. The reproductive number of COVID-19 is higher compared to SARS coronavirus. J Travel Med. 2020 Mar 13;27(2):taaao21. [PMID: 32052846]
[19] Kwok KO, Lai F, Wei WI, Wong SYS, Tang JWT. Herd immunity - estimating the level required to halt the COVID-19 epidemics in affected countries. J Infect. 2020 Jun;8o(6):e32-33. [PMID: 32209383]

[20] Clemente-Suárez VJ, Hormeño-Holgado A, Jiménez M, Benitez-Agudelo JC, Navarro-Jiménez E, Perez-Palencia N, Maestre-Serrano R, LabordeCárdenas CC, Tornero-Aguilera JF. Dynamics of Population Immunity Due to the Herd Effect in the COVID-19 Pandemic. Vaccines (Basel). 2020 May 19;8(2):236. [PMID: 32438622]

[21] Gittings K, Matson KL. Establishing herd immunity against Ebola through vaccination. Vaccine. 2016 May 23;34(24):2644-47. [PMID: 27126272]

[22] Hilyard KM, Quinn SC, Kim KH, Musa D, Freimuth VS. Determinants of Parental Acceptance of the H1N1 Vaccine. Health Educ Behav. 2014 Jun;41(3):307-14. [PMID: 24369176]

[23] Malik AA, McFadden SM, Elharake J, Omer SB. Determinants of COVID-19 vaccine acceptance in the US. EClinicalMedicine. 2020 Sep;26:100495. [PMID: 32838242]

[24] Tai W, He L, Zhang X, Pu J, Voronin D, Jiang S, Zhou Y, Du L. Characterization of the receptor-binding domain (RBD) of 2019 novel coronavirus: implication for development of RBD protein as a viral attachment inhibitor and vaccine. Cell Mol Immunol. 2020 Jun;17(6):613-20. [PMID: 32203189]

[25] Khailany RA, Safdar M, Ozaslan M. Genomic characterization of a novel SARS-CoV-2. Gene Rep. 2020 Jun;19:100682. [PMID: 32300673]

[26] D'Arienzo M, Coniglio A. Assessment of the SARS$\mathrm{CoV}-2$ basic reproduction number, $\mathrm{R}_{0}$, based on the early phase of COVID-19 outbreak in Italy. [PMID: 32835209]

[27] Aghaali M, Kolifarhood G, Nikbakht R, Saadati HM, Hashemi Nazari SS. Estimation of the serial interval and basic reproduction number of COVID-19 in Qom, Iran, and three other countries: A data-driven analysis in the early phase of the outbreak. Transbound Emerg Dis. 2020 May 30:10.1111/tbed.13656. [PMID: 32473049]

[28] Peng YD, Meng K, Guan HQ, Leng L, Zhu RR, Wang BY, He MA, Cheng LX, Huang K, Zeng QT. [Clinical characteristics and outcomes of 112 cardiovascular disease patients infected by 2019nCoV]. Zhonghua Xin Xue Guan Bing Za Zhi. 2020 Jun 
24;48(6):450-55. Chinese. [PMID: 32120458]

[29] Meng Y, Wu P, Lu W, Liu K, Ma K, Huang L, Cai J, Zhang H, Qin Y, Sun H, Ding W, Gui L, Wu P. Sexspecific clinical characteristics and prognosis of coronavirus disease-19 infection in Wuhan, China: A retrospective study of 168 severe patients. PLoS Pathog. 2020 Apr 28;16(4):e1008520. [PMID: 32343745]

[30] Liu Y, Eggo RM, Kucharski AJ. Secondary attack rate and superspreading events for SARS-CoV-2. Lancet. 2020 Mar 14;395(10227):e47. [PMID: 32113505]

[31] Gomes MGM, Corder RM, King JG, Langwig KE, Souto-Maior C, Carneiro J, Goncalves G, PenhaGoncalves C, Ferreira MU, Aguas R. Individual variation in susceptibility or exposure to SARS-CoV-2 lowers the herd immunity threshold. medRxiv [Preprint]. 2020 May 2:2020.04.27.20081893. [PMID: 32511451]

[32] Lourenco J, Pinotti F, Thompson C, Gupta S. The impact of host resistance on cumulative mortality and the threshold of herd immunity for SARS-CoV-2. medRxiv. 2020 Jan 1.

[33] Syal K. COVID-19: Herd immunity and convalescent plasma transfer therapy. J Med Virol. 2020 Apr 13:10.1002/jmv.25870. [PMID: 32281679]

[34] Thanh Le T, Andreadakis Z, Kumar A, Gómez Román R, Tollefsen S, Saville M, Mayhew S. The COVID-19 vaccine development landscape. Nat Rev Drug Discov. 2020 May;19(5):305-306. [PMID: 32273591]

[35] Graham BS. Rapid COVID-19 vaccine development. Science. 2020 May 29;368(6494):94546. [PMID: 32385100]

[36] La Maestra S, Abbondandolo A, De Flora S. Epidemiological trends of COVID-19 epidemic in Italy over March 2020: From 1000 to 100 ooo cases. J Med Virol. 2020 Apr 21:10.1002/jmv.25908. [PMID: 32314804]

[37] Wissel BD, Van Camp PJ, Kouril M, Weis C, Glauser TA, White PS, Kohane IS, Dexheimer JW. An interactive online dashboard for tracking COVID-19 in U.S. counties, cities, and states in real time. J Am Med Inform Assoc. 2020 Jul 1;27(7):1121-25. [PMID: 32333753]

[38] Papachristodoulou E, Kakoullis L, Parperis K, Panos G. Long-term and herd immunity against SARS-
CoV-2: implications from current and past knowledge. Pathog Dis. 2020 Apr 1;78(3):ftaao25. [PMID: 32510562]

[39] Rokni M, Ghasemi V, Tavakoli Z. Immune responses and pathogenesis of SARS-CoV-2 during an outbreak in Iran: Comparison with SARS and MERS. Rev Med Virol. 2020 May;30(3):e2107. [PMID: 32267987]

[40] Dhochak N, Singhal T, Kabra SK, Lodha R. Pathophysiology of COVID-19: Why Children Fare Better than Adults? Indian J Pediatr. 2020 Jul;87(7):537-46. [PMID: 32410003]

[41] Zhang Y, Xu J, Jia R, Yi C, Gu W, Liu P, Dong X, Zhou H, Shang B, Cheng S, Sun X, Ye J, Li X, Zhang J, Ling Z, Ma L, Wu B, Zeng M, Zhou W, Sun B. Protective humoral immunity in SARS-CoV-2 infected pediatric patients. Cell Mol Immunol. 2020 Jul;17(7):768-70. [PMID: 32382126]

[42] Wölfel R, Corman VM, Guggemos W, Seilmaier M, Zange S, Müller MA, Niemeyer D, Jones TC, Vollmar P, Rothe C, Hoelscher M, Bleicker T, Brünink S, Schneider J, Ehmann R, Zwirglmaier K, Drosten C, Wendtner C. Virological assessment of hospitalized patients with COVID-2019. Nature. 2020 May;581(7809):465-69. [PMID: 32235945]

[43] Zhao J, Yuan Q, Wang H, Liu W, Liao X, Su Y, Wang X, Yuan J, Li T, Li J, Qian S, Hong C, Wang F, Liu Y, Wang Z, He Q, Li Z, He B, Zhang T, Fu Y, Ge S, Liu L, Zhang J, Xia N, Zhang Z. Antibody responses to SARS-CoV-2 in patients of novel coronavirus disease 2019. Clin Infect Dis. 2020 Mar 28:ciaa344. [PMID: 32221519]

[44] Wu F, Wang A, Liu M, Wang Q, Chen J, Xia S, et al. Neutralizing antibody responses to SARS-CoV-2 in a COVID-19 recovered patient cohort and their implications. SSRN Electron J. 2020.

[45] Tan C, Huang Y, Shi F, Tan K, Ma Q, Chen Y, Jiang $\mathrm{X}, \mathrm{Li}$ X. C-reactive protein correlates with computed tomographic findings and predicts severe COVID-19 early. J Med Virol. 2020 Jul;92(7):856-62. [PMID: 32281668]

[46] Wang L. C-reactive protein levels in the early stage of COVID-19. Med Mal Infect. 2020 Jun;50(4):332-34. [PMID: 32243911]

[47] Wang M, Li M, Ren R, Li L, Chen EQ, Li W, Ying B. International Expansion of a Novel SARS-CoV-2 Mutant. J Virol. 2020 Jun 1;94(12):eoo567-20. [PMID: 
Citation: Halim M, Halim A, Trivana V. Analysing and Interpreting the Concept and Possible Implementation of Herd Immunity in the Human Population against COVID 19 Infections. J Health Care and Research. 2020 Oct 30;1(3):172-81.

\section{Literature Review}

\section{$32269121]$}

[48] Dawood AA. Mutated COVID-19 may foretell a great risk for mankind in the future. New Microbes New Infect. 2020 Apr 4;35:100673. [PMID: 32292587] [49] Faust JS, Del Rio C. Assessment of Deaths From COVID-19 and From Seasonal Influenza. JAMA Intern Med. 2020 Aug 1;18o(8):1045-46. [PMID: 32407441]
[50] Echevarría-Zuno S, Mejía-Aranguré JM, MarObeso AJ, Grajales-Muñiz C, Robles-Pérez E, GonzálezLeón M, Ortega-Alvarez MC, Gonzalez-Bonilla C, Rascón-Pacheco RA, Borja-Aburto VH. Infection and death from influenza A $\mathrm{H}_{1} \mathrm{~N}_{1}$ virus in Mexico: a retrospective analysis. Lancet. 2009 Dec 19;374(9707):2072-79. [PMID: 19913290] 